\title{
Fizioterapijski protokol kod odraslih bolesnika nakon traumatske ozljede mozga
}

${ }_{1}$ Zdravko Maček

1 Mario Kolar

1 Krešimir Stubičar

1 Mario Mandić

1 Specijalna bolnica za medicinsku rehabilitaciju Krapinske Toplice

\section{Sažetak}

Uvod. Protokoli obuhvaćaju smjernice i preporuke fizioterapeuta, liječnika i ostalih članova tima u rehabilitaciji bolesnika nakon traumatskih ozljeda mozga (TOM). Traumatske ozljede mozga posljedica su djelovanja fizičke sile koje uzrokuje primarna ili sekundarna oštećenja mozga. Nakon ozljede mozga funkcionalni status bolesnika može biti u rasponu od sposobnosti aktivnog sudjelovanja u rehabilitacijskim procesima, do stanja vigilne kome ili perzistentnoga vegetativnog stanja. Cilj i svrha izrade protokola jest osiguranje standarda kvalitete i ujednačenost fizioterapijskih postupaka u procesu neurorehabilitacije odraslih bolesnika s TOM-om. Protokol definira metode procjene, postavljanje ciljeva te metode fizioterapijske intervencije. Metode. Izrada fizioterapijskog protokola temelji se na pregledu relevantne literature s područja neurofizioterapije, koja uključuje kliničke smjernice, znanstvene i stručne članke te sekundarne izvore informacija. Rezultati i rasprava. Fizioterapijska procjena sastoji se od pregleda, testova i mjerenja. Preporučeni standard procjene sadrži skalu za procjenu razine nesposobnosti (Disability Rating Scale), modificiranu Ashworthovu skalu, Test „ustani i idi” (Timed Up and Go Test), Test ustajanja (Sit to Stand Test), Bergovu skalu balansa (Berg Balance Scale), vizualno-analognu skalu boli i goniometriju. Planiranje i provedba fizioterapeutske intervencije kod bolesnika u komi, vegetativnom statusu i minimalnoj svjesnosti uključuje: prevenciju komplikacija inaktiviteta, multisenzoričku stimulaciju svijesti, facilitaciju transfera, pozicioniranje u kolicima te facilitaciju kontrole glave, trupa i voljnih pokreta ekstremiteta. Planiranje i provedba fizioterapeutske intervencije kod bolesnika koji aktivno sudjeluju u terapijskim procesima dodatno uključuje: specifičnu mobilizaciju mišića, stimulaciju aktivnosti mijenjanja položaja u ležanju, uspravljanja u sjedeći položaj i sjedenja, ustajanja iz sjedećeg u stojeći položaj i stajanja, reedukaciju hoda, funkcionalni trening gornjih ekstremiteta, vježbe balansa i koordinacije, vježbe snage i izdržljivosti, primjenu ortoza te edukaciju bolesnika i obitelji. Zaključak. Fizioterapijski protokol može osigurati ujednačenost i kvalitetu izvođenja fizioterapijskih postupaka u rehabilitaciji odraslih bolesnika s TOM-om, pri čemu se preporučene metode procjene i tretmana temelje na znanstvenim i stručnim dokazima učinkovitosti.

Ključne riječi: neurofizioterapija, TOM, protokol, procjena, intervencija

Datum primitka: 15.07.2018.

Datum prihvaćanja: 07.10.2018.

DOI: $10.24141 / 1 / 4 / 2 / 13$

Adresa za dopisivanje:

Zdravko Maček

Specijalna bolnica za medicinsku rehabilitaciju, Gajeva 2, 49217 Krapinske Toplice

tel.: +385915192254

e-pošta: zmacek.ftkco@sbkt.hr 


\section{Uvod}

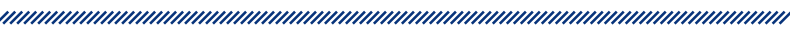

Najstariji pisani dokument koji govori o ozljedama glave i njihovu liječenju potječe iz 1700 . g. pr. Kr. Na Papirusu Edwina Smitha opisane su depresivne frakture lubanje te preporuka ostavljanja rane otvorenom u svrhu drenaže. $O$ otvorima na lubanji, tzv. „trepanaciji”, u svrhu liječenja ozljeda glave govori i Homer u svojoj Ilijadi. Konkretniji zapisi o kirurškim postupcima područja glave potječu iz razdoblja Rimskog Carstva i Galena koji opisuje liječenje ozljeda glave kod gladijatora te prvi put povezuje ozljede mozga s kontralateralnim parezama i paralizama udova. ${ }^{1}$

Traumatske ozljede mozga (TOM) jesu ozljede moždanog tkiva koje privremeno ili trajno oštećuju moždanu funkciju. $U$ incidenciji TOM-a vodeći su uzroci prometne nesreće (70\%), a zatim slijede sportske povrede, padovi, nasilne ozljede i ranjavanja. Populacija u kojoj se događaju traumatske ozljede mozga najčešće su muškarci (88\%) prosječne dobi 34,2 godine.,3,4 Dijagnoza se postavlja klinički, a potvrđuje se kompjuteriziranom tomografijom (CT) ili magnetskom rezonancijom (MR). Liječenje se u početku sastoji od potpore disanja, oksigenacije i krvnog tlaka kako bi se spriječila daljnja oštećenja moždanog tkiva, a kasnije prema potrebi uključuje kirurški zahvat i rehabilitaciju. Otvorene ozljede obuhvaćaju penetraciju kroz kosti lubanje te obično kroz moždane ovojnice i moždano tkivo. ${ }^{2}$

Do zatvorenih ozljeda dolazi prilikom udarca u glavu, što uzrokuje brzu akceleraciju i deceleraciju mozga. Akceleracija ili deceleracija mogu oštetiti tkivo na mjestu udarca, na mjestu suprotnom od njega ili difuzno. Aksoni i krvne žile ozljeđuju se te dovode do kontuzija, intracerebralnih ili subarahnoidalnih krvarenja, epiduralnih i subduralnih hematoma. ${ }^{2,5}$ TOM uzrokuju primarna ili sekundarna oštećenja mozga, što uzrokuje poremećaje svijesti, živčano-mišićnih i kognitivnih sposobnosti te moguće poremećaje ponašanja. ${ }^{2,4,5}$ Traumatske se ozljede mozga prema težini oštećenja moždanih tkiva dijele na lake ( $85 \%)$, umjerene (15\%) i teške $(5 \%) .{ }^{2}$ Kod lakih povreda nije potrebna rehabilitacija i fizioterapija, dok je kod srednjih i teških povreda nužna za oporavak motoričkog funkcioniranja, često je dugotrajna i kompleksna. ${ }^{2,3}$ Ovisno o oštećenju tjelesnih struktura i funkcija, ograničenju aktivnosti i smanjenju participacije u društvu, bolesnici s TOM-om dijele se na bolesnike koji mogu aktivno sudjelovati u rehabilitacijskim procesi- ma, u stanju vigilne kome (CV), u perzistentnom vegetativnom stanju (PVS) i bolesnike u minimalno svjesnom stanju (MCS). ${ }^{4,5}$

U rehabilitaciji funkcionalnoga motoričkog oporavka osoba s TOM-om važnu ulogu zauzima fizioterapija. ${ }^{4,5,6}$ Fizioterapija je zdravstvena profesija usmjerena pojedincima i populaciji u cilju razvoja, održavanja i vraćanja maksimalne pokretljivosti i funkcionalne sposobnosti tijekom cijeloga životnog vijeka. ${ }^{7}$ Područje su djelovanja fizioterapije sve okolnosti u kojima je funkcionalna pokretljivost ugrožena starenjem, ozljedama, boli, bolestima i poremećajima odnosa faktora okoline i pojedinca. ${ }^{7}$ Neurofizioterapija je područje fizioterapije koje se bavi motoričkim deficitima koji nastaju zbog patoloških oštećenja u živčanom sustavu. ${ }^{4,5,8}$

Uz standardan neurofizioterapijski tretman, razvijeni su drugi neurološki koncepti i tehnike koji se primjenjuju u rehabilitaciji osoba koje su pretrpjele TOM. Neki su od važnijih: koncept Bobath, koncept PNF (Proprioceptive Neuromuscular Facilitation), Vojtin koncept, tretman MRP (Motor Relearning Programme) te tehnike kao što su CIMT (Constraint-induced movement therapy), terapija ogledalom (engl. mirror therapy) i slično. ${ }^{6,8}$ Tretman bolesnika s TOM-om može se provoditi na akutnim neurološkim i neurokirurškim odjelima, na odjelima stacionarne bolničke rehabilitacije ili u kući pacijenta. . $^{2,46}$

Protokol je pisani dokument sačinjen od skupa preporuka koje usmjeravaju medicinskog stručnjaka prema provođenju predviđenih procedura postupanja. To je dokument kojim se sistematiziraju i standardiziraju postupci te se tako olakšava rad nadležnih stručnjaka. ${ }^{9}$ Fizioterapijski protokol obuhvaća smjernice i preporuke fizioterapeuta, fizijatara, neurologa, neurokirurga i ostalih članova tima u rehabilitaciji bolesnika nakon bolesti ili povreda središnjega živčanog sustava (SŽS). Kod odraslih bolesnika s oštećenjem SŽS-a fizioterapeuti primjenjuju protokol prema kompetencijama na odjelima akutnog liječenja i rehabilitacije te tijekom ambulantnog liječenja, u centrima za njegu ili bolesnikovu domu. ${ }^{10}$ Odstupanja od protokola ovise o prijašnjoj razini funkcije, općem zdravlju i ciljevima bolesnika, dostupnoj opremi i preporukama liječnika. Odgovornost i ovlaštenja za postupke procjene, planiranja i fizioterapijske intervencije po uputi liječnika provode članovi fizioterapeutskog tima: magistri fizioterapije, diplomirani fizioterapeuti i prvostupnici fizioterapije. ${ }^{10}$

U procesu neurofizioterapije fizioterapeut se koristi modelom kliničkog zaključivanja. Ovaj model podrazumijeva uočavanje problema bolesnika na razini participa- 
cije, aktivnosti, tjelesnih struktura i funkcija te njihovu analizu, razumijevanje, diferencijaciju i konačno definiranje problema $\mathrm{u}$ okviru fizioterapeutske procjene. ${ }^{11} \mathrm{U}$ okviru pristupa rješavanju problema fizioterapeut provodi procjenu, ispunjava fizioterapeutski karton, donosi ciljeve, plan i program fizioterapije te provodi fizioterapeutsku intervenciju i evaluaciju procesa. ${ }^{10}$

Cilj je i svrha izrade fizioterapijskog protokola za tretman odraslih bolesnika nakon TOM-a da osigura standardnu kvalitetu i ujednačenost fizioterapijskih postupaka u procesu neurorehabilitacije. Protokol definira metode procjene, postavljanje ciljeva te metode fizioterapijske intervencije.

\section{Metode}

Izrada fizioterapijskog protokola kod odraslih bolesnika nakon TOM-a temelji se na pregledu relevantne literature s područja neurofizioterapije, koja uključuje kliničke smjernice, znanstvene i stručne članke te sekundarne izvore informacija. Prilikom izrade fizioterapijskog protokola usklađivani su suvremeni znanstveni i stručni dokazi s ekonomskim, pravnim, kadrovskim i prostornim mogućnostima kliničke primjene u Hrvatskoj.

\section{Fizioterapijski protokol}

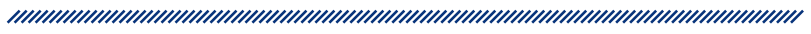

Fizioterapijski protokol kod odraslih bolesnika nakon TOM-a slijedi pristup rješavanja problema i model kliničkog zaključivanja. Kliničko zaključivanje podrazumijeva procjenu funkcionalnih oštećenja, postavljanje ciljeva tretmana, plan i izbor metoda tretmana, fizioterapijsku intervenciju te evaluacijske procjene i završnu procjenu rezultata tretmana. ${ }^{12,13,14}$ Fizioterapijska procjena sastoji se od fizioterapeutskog pregleda i odgovarajućih testova i mjerenja, a rezultati procjene upisuju se u fizioterapeutski karton. Obvezna je početna procjena prilikom prijama bolesnika te završna procjena prilikom otpusta bolesnika s rehabilitacije. Periodična evaluacija provodi se prema indikaciji, ovisno o ciljevima rehabilitacije, promjenama statusa bolesnika i trajanju rehabilitacije. ${ }^{2,6,15,16}$ Metode fizioterapijske intervencije usklađene su s medicinskom dijagnozom i nalazima fizioterapijske procjene, a temeljene su na stručnim i znanstvenim dokazima učinkovitosti. ${ }^{12,13,14}$

\subsection{Metode fizioterapijske procjene pacijenata s TOM}

Preporučeni standard procjene u akutnoj fazi oporavka, koja uključuje i bolesnika u jedinici intenzivnog liječenja, sadrži skalu za procjenu razine nesposobnosti (Disability Rating Scale), a prema indikaciji modificiranu Ashworthovu skalu i goniometriju. U kasnijim fazama oporavka nastavljaju se primjenjivati metode procjene iz rane faze, a dodatno se prema indikacijama uključuje Test „ustani i idi” (Timed Up and Go Test), Test ustajanja (Sit to Stand Test), Bergova skala balansa (Berg Balance Scale) i vizualno-analogna skala boli. ${ }^{17}$

\subsubsection{Fizioterapeutski karton}

Fizioterapeutski je karton dokument koji je propisan Zakonom o fizioterapeutskoj djelatnosti u RH. ${ }^{10} \mathrm{Njegov}$ sadržaj propisan je standardima koje je donijela Hrvatska komora fizioterapeuta. ${ }^{18}$ Sadrži opće podatke o bolesniku i funkcionalnu fizioterapeutsku procjenu bolesnika. Funkcionalna fizioterapijska procjena zasniva se na modelu procjene prema Međunarodnoj klasifikaciji funkcioniranja, onesposobljenja i zdravlja. ${ }^{11}$ Fizioterapeutski karton sadrži opće podatke o bolesniku kao što su: ime i prezime, dob, spol, zanimanje, broj upisa na rehabilitaciju, datum prijama i otpusta bolesnika s rehabilitacije te medicinska dijagnoza. U fizioterapeutski karton nadležan fizioterapeut upisuje podatke o funkcionalnoj fizioterapeutskoj procjeni bolesnika na temelju pregleda i provedenih odgovarajućih testova i mjerenja, cilj i plan fizioterapije, periodičnu evaluaciju te datum pružene usluge. Vjerodostojnost podataka potvrđuje odgovorni fizioterapeut potpisom i faksimilom. ${ }^{19}$

\subsubsection{Skala za procjenu razine nesposobnosti (Disability Rating Scale, DRS)}

Procjenjuje kategorije sposobnosti funkcioniranja bolesnika s TOM-om. U procjeni sadrži kategorije pobuđenosti, svjesnosti i odgovornosti, kognitivne sposobnosti za samozbrinjavanje, ovisnost o tuđoj pomoći te psihološku prilagođenost. Zbroj pojedinačnih rezultata određuje kategorije nesposobnosti. ${ }^{20}$ Skala procjene onesposobljenosti primjenjuje se za osobe s traumatskom 
ozljedom mozga s rasponom rezultata od perzistentnoga vegetativnog stanja do pune participacije u okolini te se primjenjuje i za klinička istraživanja oporavka kod bolesnika s TOM-om. Skala sadrži osam područja: sposobnost otvaranja očiju, sposobnost komunikacije, motorički odgovor, sposobnost hranjenja, obavljanje toalete, oblačenje, razina funkcioniranja u okolini i razina radne sposobnosti. Svako se područje mjeri u rasponu od 0 do 3 ili od 0 do 5 bodova.

Interpretacija rezultata skale onesposobljenosti označava razinu onesposobljenosti. Rezultat 0 znači da bolesnik nema onesposobljenja, 1 bod znači vrlo blago onesposobljenje, 2 do 3 boda djelomično onesposobljenje, 4 do 6 bodova govore o umjerenom onesposobljenju, 7 do 11 bodova znače umjereno ozbiljno onesposobljenje, 12 do 16 bodova znače ozbiljno onesposobljenje, 17 do 21 bod znače vrlo ozbiljno onesposobljenje, 22 do 24 boda označavaju osobu u vegetativnom stanju i 25 do 29 bodova označavaju osobu u ekstremnom vegetativnom stanju. ${ }^{20}$

\subsubsection{Modificirana Ashworthova skala (mAS) za procjenu spastičnosti}

Modificiranom Ashworthovom skalom procjenjuje se otpor na pasivno pokretanje ekstremiteta, a testiranje se provodi u supiniranom položaju. ${ }^{21}$ Primjenjuje se po indikaciji kod bolesnika s hipertonusom kao posljedicom oštećenja gornjega motoričkog neurona. Razine hipertonusa na modificiranoj Ashworthovoj skali rangirane su od 0 do 4, pri čemu ocjena 0 označava da nema povećanja mišićnog tonusa, ocjena 1 označava lagano povišenje tonusa $s$ hvatanjem i otpuštanjem ili minimalni otpor na kraju raspona pokreta fleksije ili ekstenzije, ocjena 1+ označava minimalno povišenje tonusa s hvatanjem i otpuštanjem ili minimalni otpor kroz manje od pola raspona pokreta, ocjena 2 označava izraženiji otpor kroz cijeli raspon pokreta, ali se zahvaćeni dio pokreće u punom rasponu pokreta, ocjena 3 označava znatno povišenje tonusa uz otežan pokušaj pasivnog pokretanja, a ocjena 4 označava da je zahvaćeni ekstremitet rigidan u položaju fleksije ili ekstenzije. ${ }^{21}$

\subsubsection{Test ,ustani i idi” (Timed Up and Go Test, TugT)}

Izvodi se tako da se u sekundama mjeri vrijeme ustajanja bolesnika sa standardnog stolca, hod po ravnom duljine $3 \mathrm{~m}$, okretanje, hod do stolca i sjedanje. Test se provodi po indikaciji kod svih bolesnika koji imaju ba- rem minimalnu funkciju hoda. Ako se pri testiranju bolesnik koristi pomagalom, obvezno se bilježi vrsta pomagala. ${ }^{22}$ Rezultat je interval u sekundama koji korelira s razinom samostalnosti u kretanju, pri čemu rezultat manji od 20 sekundi označava samostalno pokretnu osobu, od 20 do 29 sekundi teže pokretnu i nesigurnu osobu, a rezultat veći od 30 sekundi govori o osobi kojoj je potrebna pomoć pri kretanju. ${ }^{22}$

\subsubsection{Test ustajanja sa stolca (Sit to Stand Test, StST)}

Test se sastoji od zahtjeva bolesniku da ustane sa standardnog stolca, sjedne i ponovno ustane u trajanju od 30 sekundi. Registrira se broj ponavljanja ustajanja u uspravni stav koji korelira s rizikom za pad. Test se provodi po indikaciji kod svih bolesnika koji imaju barem minimalnu funkciju uspravljanja iz sjedenja u stajanje bez pomoći ruku ili druge osobe. Frekvencija ustajanja veća od 13 sekundi predstavlja mali rizik od pada, od 9 do 12 , umjereni, a manje od 8 predstavlja veliki rizik od pada. ${ }^{23}$

\subsubsection{Procjena intenziteta boli (vizualno-analogna skala, VAS)}

Mjerenje se provodi po indikaciji kod svih bolesnika koji subjektivno izražavaju bol. Mjeri se u mirovanju i tijekom aktivnosti. ${ }^{24}$ Vizualno-analogna skala boli jest kontinuirana linija dužine 10 centimetara $(100 \mathrm{~mm})$ te je na krajevima označena dvama ekstremnim simptomima boli i verbalnim opisom. ${ }^{25}$ Oznaka 0 znači da nema boli, dok se drugi ekstrem opisuje kao „najgora bol što može biti” ili „najteža bol koju se može zamisliti” i označuje se rezultatom 100 (100 mm na skali). ${ }^{26}$ Od ispitanika se traži da opiše sadašnju bol ili bol u posljednja 24 sata te mora na skali označiti intenzitet boli. Viši rezultat podrazumijeva veću bol. $U$ interpretaciji rezultata preporučuje se: nema boli $0-4$, srednja bol $5-44$, umjerena bol 45 - 74 te jaka bol $75-100 .{ }^{27}$

\subsubsection{Goniometrija za procjenu opsega pokreta zglobova}

Mjerenje se provodi po indikaciji kod bolesnika koji imaju ograničenja opsega pokreta u pojedinim zglobovima. Angularni (fiziološki) pokreti mjere se iz nultog položaja, ako je to moguće, oko definirane osi. Može se mjeriti aktivni ili pasivni opseg pokreta, a dobiveni rezultati usporedivi su s priznatim normama ili s opsegom pokreta 
zdrave strane. Rezultati ovog testa mogu ukazivati na smanjeni opseg pokreta, hipomobilnost, ili opseg pokreta veći od norme, hipermobilnost. Goniometrijskim mjerenjem moguće je ustanoviti kapsularni obrazac i skraćenje muskulature te se može izmjeriti kontraktura. Zglob može biti hipomobilan u jednom smjeru, a hipermobilan u suprotnom smjeru. ${ }^{28}$

\subsection{Metode fizioterapijske intervencije}

Planiranje i provedba fizioterapijske intervencije u akutnoj fazi i kod bolesnika u komi, vegetativnom statusu i minimalnoj svjesnosti uključuju: prevenciju komplikacija inaktiviteta, multisenzoričku stimulaciju svijesti, pozicioniranje u krevetu, facilitaciju transfera u krevetu i transfera u kolica, pozicioniranje u kolicima te facilitaciju kontrole glave, trupa i voljnih pokreta ekstremiteta. Fizioterapijska intervencija u akutnoj fazi liječenja i oporavka u jedinici intenzivnog liječenja mora biti pod nadzorom ili usuglašena s nadležnim liječnikom (neurokirurg, neurolog, anesteziolog). ${ }^{17}$

Planiranje i provedba fizioterapijske intervencije kod bolesnika u kasnijim fazama oporavka i onih koji aktivno sudjeluju u terapijskim procesima podrazumijeva nastavak fizioterapijskih intervencija iz rane faze, ali postaju intenzivnije, aktivnije i dužeg trajanja. $U$ fazi intenzivne medicinske rehabilitacije fizioterapijska intervencija dodatno uključuje: specifičnu mobilizaciju mišića, stimulaciju aktivnosti mijenjanja položaja u ležanju, uspravljanja u sjedeći položaj i sjedenja, ustajanja iz sjedećeg u stojeći položaj i stajanja, reedukaciju hoda, funkcionalni trening gornjih ekstremiteta, vježbe balansa i koordinacije, vježbe snage i izdržljivosti, primjenu ortoza te edukaciju bolesnika i obitelji. 2, $4,5,6,15^{2}$

\subsubsection{Pozicioniranje bolesnika u krevetu}

Pozicioniranje se provodi u oba bočna položaja, supiniranom položaju te, ako je moguće, i u proniranom položaju. Pravilnim pozicioniranjem bolesnika u krevetu sprječavaju se komplikacije inaktiviteta (kontrakture, dekubitusi, pneumonije, tromboza, heterotopne osifikacije) i potiče se somatosenzorički input potreban za normalizaciju svijesti i motoričke kontrole putem vođenja prijelaza iz jednog u drugi položaj te putem održavanja optimalnog alignmenta u ležećim položajima. ${ }^{4,5,6,15,16,29,30}$ U svakom od navedenih položaja primjenjuju se modifikacije položaja koje uključuju različite kombinacije fizioloških položaja gornjih i donjih ekstremiteta u odnosu na zdjelicu, trup i glavu. Uz modifikaciju položaja segmena- ta tijela, pozicioniranje uključuje i modifikaciju okoline tijelu bolesnika, što uključuje podupiranje nestabilnih, neaktivnih ili ukočenih dijelova tijela kako bi se osiguralo održavanje optimalnoga fiziološkog položaja bolesnika u krevetu. ${ }^{6,15,16,30,31}$ Prijelaz iz jednog položaja u drugi provodi se terapeutskim vođenjem pokreta/aktivnosti preko normalnih obrazaca pokretanja svojstvenih za izvođeni pokret/aktivnost. ${ }^{6,15,16,30,31}$ Prilikom vođenja prijelaza iz jednog položaja u drugi položaj stimulira se aktivnost. Vrijeme održavanja položaja prilagođava se problemima/ ciljevima, a maksimalno zadržavanje položaja ne smije biti duže od dva sata. Prostor i aktivnosti koje se provode s bolesnikom i na bolesniku treba prilagoditi tako da bolesnik ima veći priljev (input) informacija sa strane tijela koja je oštećenija. ${ }^{5,6,15,31,32}$ Potrebno je izbjegavati nabore na posteljini te obratiti pažnju na cijevi instrumenata ispod bolesnika.

Položaj na boku jest asimetričan, što omogućuje inhibiciju fleksijske ili ekstenzijske spastičnosti i tako pomaže normaliziranju mišićnog tonusa. Pozicioniranjem u oba bočna položaja potiču se mehanizmi recipročne inervacije te se bolesniku omogućuje bolja percepcija slike vlastitog tijela. Pozicioniranjem na oštećeni bok bolesniku se pruža mogućnost da proprioceptivno i taktilno osjeti oštećeno područje tijela, a time se potiču i normalne reakcije podupiranja. Supinirani i pronirani položaj treba često modificirati i prilagoditi bolesnikovim individualnim problemima. Modifikacije se odnose na položaj udova i glave u odnosu na trup, a njima se ostvaruje specifičan cilj da bolesnik percipira različite položaje pojedinih segmenata tijela.6,15,16,30,32,33

\subsubsection{Multisenzorička stimulacija $i$ mobilizacija mekih tkiva i zglobova}

Multisenzorička stimulacija omogućava bolesniku auditivne, vizualne, olfaktorne i gustatorne podražaje u svrhu oporavka svijesti i prepoznavanja vlastitog tijela i okoline. ${ }^{5,16,34,35}$ Ciljevi su: stimulacija senzoričkih sustava i održavanje elastičnosti mekih tkiva i pokretljivost zglobova. Svrha je mobilizacije mekih tkiva i zglobova stimulacija somatosenzoričkog sustava za postizanje oporavka svijesti i motoričke kontrole. Mobilizacijom kože, mišića, tetiva i veziva stimulira se proprioceptivni osjet, održava se elastičnost mekih tkiva i pokretljivost zglobova. ${ }^{5,7,36,37}$ Provodi se barem jedanput dnevno. U provođenje multisenzoričke stimulacije potrebno je uključiti i obitelj bolesnika. ${ }^{34,38}$ Potrebno je izbjegavati agresivne mobilizacije, izazivanje boli i provociranje spazma te prejake senzoričke stimulacije. 
Specifična mobilizacija jest manualna fizioterapeutska tehnika kojom se nastoji poboljšati mobilnost zglobova i mekih tkiva (mišića, tetiva, zglobnih čahura i ligamenata), uspostaviti bolji alignment tjelesnih struktura i poboljšati cirkulaciju tretiranog područja. Navedenim se pozitivno djeluje na metabolizam, strukturu i funkciju muskulature. ${ }^{5}$ Specifična mobilizacija muskulature i korekcija alignmenta omogućuje bolesniku normalizaciju tonusa i bolje preduvjete za motoričku kontrolu. Kroz terapijsko vođenje bolesnik prima normalnu, tj. ispravljenu informaciju odnosa između različitih dijelova tijela, kao i između tijela i okoline, što omogućuje bolji temelj za postizanje terapijskog cilja. Istodobno dobra informacija i stimulacija kod bolesnika mogu uzrokovati osjećaj prepoznavanja pokreta, aktivnosti ili funkcije. . $39,40^{2}$

\subsubsection{Facilitacija transfera iz kreveta u kolica i obratno}

Facilitacija transfera iz kreveta u kolica uključuje stimulaciju uspravljanja iz ležećeg položaja u sjedeći položaj, stimulaciju uspravljanja iz sjedećeg položaja prema stojećem položaju s osloncem na stopala na podu, rotaciju tijela prema kolicima i ekscentrično spuštanje u sjedeći položaj na kolicima. Navedene faze aktivnosti izvode se u optimalno normalnim obrascima pokreta/aktivnosti te se osigurava stabilnost i mobilnost segmenata tijela u skladu s funkcionalnim statusom bolesnika. Facilitacija transfera iz kreveta u kolica stimulira reakcije uspravljanja i aktivnosti bolesnika te omogućava dugotrajnije zadržavanje adaptiranoga sjedećeg položaja. ${ }^{6}$ Transfer iz kolica u krevet provodi se na isti način, ali u obratnom redoslijedu komponenti pokreta/aktivnosti. Transfer provodi jedan ili više fizioterapeuta, ovisno o funkcionalnim sposobnostima bolesnika. Transfer u kolica provodi se čim medicinsko stanje bolesnika to omogućuje, odnosno po dopuštenju nadležnog liječnika. ${ }^{6,33}$ Provodi se analiza i procjena mogućnosti transfera individualno za bolesnika te se nakon toga educira njegovatelje o preporučenom transferu kako bi se provodio tijekom dana. Primjenjuju se tehnike facilitacije koje sprječavaju da terapeut/njegovatelj podiže teret veći od $20 \mathrm{~kg}$. Transfer se izvodi tiho, nježno i polako kako ne bi došlo do zastrašivanja bolesnika i osjećaja padanja, kao što se događa kada se transfer izvodi na brz i iznenađujući način za bolesnika. ${ }^{15}$ Potrebno je izbjegavati hvatove na bolesniku koji mogu dovesti do istegnuća nestabilnih zglobova, posebno ramena i stopala, te izbjegavati pretjerana opterećenja na tijelo fizioterapeuta. ${ }^{6,15,16}$

\subsubsection{Pozicioniranje i adaptacija sjedenja u kolicima}

Pozicioniranje uključuje adaptaciju bolesnika na površine oslonca u sjedećem položaju u kolicima. Potrebno je u pozicioniranju slijediti optimalni alignment sjedećeg položaja, omogućiti stabilnost nestabilnim segmentima tijela i omogućiti potporu za spastične segmente tijela. ${ }^{6,8,38}$ Ciljevi su pozicioniranja i adaptacije sjedenja u kolicima: duže zadržavanje sjedećeg položaja, prolongirane stimulacije živčano-mišićnog sustava na vertikalni položaj tijela u prostoru, omogućiti mobilnost u prostoru i postizanje bolje orofacijalne kontrole, gutanje i govor te društvena interakcija. ${ }^{6,16,38}$ Glava mora biti u fiziološkom, neutralnom položaju, a donji ekstremiteti moraju biti pozicionirani na naslonima za noge tako da fleksija u kukovima ne prelazi $90^{\circ} .6,8,15$ Prilikom pozicioniranja i adaptacije sjedećeg položaja u kolicima potrebno je obratiti pažnju na individualne potrebe bolesnika za pozicioniranjem (izbjegavati iritacije korištenih potpora na dijelove tijela). ${ }^{6,15}$ Kod ranih pozicioniranja treba voditi brigu o promjenama krvnog tlaka i pulsa, disanju, znojenju te cirkulaciji. Dužina sjedenja postupno se povećava i ovisi o sposobnosti bolesnika. Poželjno je izbjegavati dugotrajno sjedenje kod bolesnika koji imaju dekubituse u područjima koja dolaze u kontakt sa sjednim površinama. ${ }^{6,15,36}$

\subsubsection{Facilitacija okretanja u bočni, pronirani i supinirani ležeći položaj}

Facilitacijom okretanja u ležećem položaju stimuliraju se reakcije uspravljanja i ravnoteže, posturalna kontrola te svjesnost bolesnika. Stimulacijom reakcija uspravljanja i ravnoteže cilj je omogućiti uspostavu automatske posturalne kontrole trupa i glave. Okretanjem bolesnika u različite položaje razvija se percepcija vlastitog tijela i okoline te se potiče integracija bolesnika u funkcionalne aktivnosti. Facilitacijom se provodi taktilna i proprioceptivna stimulacija optimalnih komponenti pokreta/ aktivnosti okretanja u ležećem položaju. ${ }^{6,8,15,16,30,40}$ Facilitaciju okretanja u ležećem položaju provodi jedan ili više fizioterapeuta, svakodnevno ili prema funkcionalnom statusu bolesnika.

\subsubsection{Facilitacija uspravljanja u sjedeći položaj i sjedenje}

Facilitacijom uspravljanja iz ležećeg položaja u sjedenje i sjedenjem stimuliraju se reakcije uspravljanja i ravnoteže, posturalna kontrola te svjesnost bolesnika. 
Cilj je omogućavanje uspostave automatske posturalne kontrole trupa i glave, poticanje razvoja percepcije vlastitog tijela i okoline te postizanje integracije u funkcionalnim aktivnostima. Facilitacijom se provodi taktilna i proprioceptivna stimulacija optimalnih komponenti pokreta/aktivnosti uspravljanja u sjedeći položaj i sjedenja. U sjedećem položaju stimuliraju se optimalni prijenosi mase tijela u svim ravninama, selektivno se mobiliziraju segmenti trupa i glave. Osiguravaju se stabilne referencije tijela u odnosu na koje se vodi pokretanje mobilnih segmenata tijela. . $, 8,16,40$ Facilitaciju uspravljanja u sjedenje i tretman sjedenja provodi jedan ili više fizioterapeuta, svakodnevno ili prema funkcionalnom statusu bolesnika. Kod bolesnika u ranoj fazi oporavka prilikom prvih facilitacija uspravljanja traži se mišljenje nadležnog liječnika. Potrebno je izbjegavati nestabilne površine oslonca za sjedenje. ${ }^{37}$

Sjedeći položaj povoljno utječe na kontrolu sfinktera, funkciju mjehura i peristaltiku crijeva. Osim fiziološkog, treba naglasiti i psihološko gledište ovih funkcija, gdje funkcija pražnjenja mokraćnog mjehura i crijeva može biti vrlo frustrirajuća za bolesnika u ležećem položaju u krevetu. ${ }^{6,15,40}$

\subsubsection{Facilitacija uspravljanja iz sjedenja u stojeći položaj i stajanje}

Facilitacijom uspravljanja iz sjedećeg položaja u stajanje i stajanjem stimuliraju se reakcije uspravljanja i ravnoteže, a cilj je uspostava automatske posturalne kontrole donjih ekstremiteta, trupa i glave. Potiče se razvoj svijesti, percepcije vlastitog tijela i okoline te omogućava integracija u funkcionalne aktivnosti. Facilitacijom se provodi taktilna i proprioceptivna stimulacija optimalnih komponenti pokreta/aktivnosti uspravljanja u stojeći položaj i stajanja. U stojećem položaju stimuliraju se optimalni prijenosi mase tijela u svim ravninama, selektivno se mobiliziraju segmenti donjih ekstremiteta, trupa i glave. Osiguravaju se stabilne referencije tijela u odnosu na mobilne segmente tijela. ${ }^{6,16,40}$ Facilitaciju uspravljanja u stajanje i tretman stajanja provode jedan ili više fizioterapeuta, svakodnevno ili prema funkcionalnom statusu bolesnika. Kod bolesnika u ranoj fazi oporavka prilikom prvih facilitacija uspravljanja traži se mišljenje nadležnog liječnika. Prema potrebi ili funkcionalnom statusu bolesnika upotrebljavaju se ortoze kada zbog abnormalno povišenog tonusa fizioterapeut ne može korigirati ili kontrolirati određene segmente tijela. Potrebno je obratiti pažnju na promjene krvnog tlaka i pulsa, disanja, znojenje te cirkulaciju. Dužina stajanja postupno se povećava i ovisi o sposobnosti bolesnika. ${ }^{6,15}$ Potrebno je izbjegavati nestabilne površine oslonca za bolesnika i za fizioterapeute, kao i pretjerana opterećenja na tijelo fizioterapeuta.

Facilitacija normalnoga selektivnog oblika uspravljanja i reakcija balansa u aktivnosti prijelaza iz sjedećega u stojeći položaj omogućuje bolesniku lakše usvajanje potrebnih komponenti i obrazaca hoda. ${ }^{16,40}$

\subsubsection{Vježbe balansa i koordinacije}

Vježbe balansa provode se u svim položajima tijela, stimuliraju se reakcije uspravljanja, ravnoteže i zaštitne reakcije. ${ }^{41}$ Cilj je vježbi balansa održavanje ravnoteže u svim položajima te sprječavanje padova prilikom zadržavanja ili promjena položaja tijela, kretanja i izvođenja različitih aktivnosti. Vježbe balansa uključuju prijenose mase tijela s dosezanjem predmeta rukama, vježbe balansa u stojećem položaju s postupnim smanjenjem baze oslonca, prijenosi mase tijela s jedne na drugu nogu naizmjence, stajanje na jednoj nozi uz pridržavanje i bez pridržavanja, vježbe na nestabilnim površinama oslonca, vježbe uz vizualnu kontrolu i bez vizualne kontrole, poligone koji uključuju balansne ploče, svladavanje prepreka, snalaženje u prostoru i svladavanje gravitacije. 2,5,40,41,42,43,44 Izbor vježbi treba prilagoditi funkcionalnom statusu bolesnika. Vježbe balansa obvezno je uključiti kod bolesnika s ataksijom te izbjegavati situacije u kojima pad može uzrokovati povrede.

Trening balansa na balansnoj platformi, uz dodatni vizualni biofeedback u usporedbi sa standardnim fizioterapijskim tretmanom, poboljšava posturalnu kontrolu, smanjuje posturalno njihanje i nestabilnost, povećava pomak zdjelice u frontalnoj ravnini, poboljšava prijenos tjelesne mase i produžuje vrijeme oslonca na paretičnu nogu. Ovakav trening balansa normalizira obrasce mišićnih aktivnosti i povećava senzornu percepciju, što rezultira znatnim napretkom u dinamičkom balansu uz normalniji i brži hod te napretkom u funkcionalnoj neovisnosti u aktivnostima svakodnevnog života. ${ }^{45}$

\subsubsection{Reedukacija hoda}

Vježbe reedukacije hoda provode se facilitacijom komponenti faza normalnog hoda. Reedukacija hoda uključuje stimulaciju faze stabilnosti i faze mobilnosti donjih ekstremiteta, uz adekvatnu posturalnu adaptaciju trupa, glave i gornjih ekstremiteta. Vježbe reedukacije hoda osiguravaju bolesniku samostalno i sigurno kretanje u zatvorenom i na otvorenom te optimalnu mobilnost 
bolesnika za obavljanje aktivnosti svakodnevnog života. Reedukacija hoda podrazumijeva integraciju naučenih komponenti faza hoda u funkcionalnu aktivnost hodanja te se provodi na različitim površinama oslon$\mathrm{ca}$, na otvorenom i u zatvorenom prostoru te na stubama. ${ }^{2,36,40,44,46,47,48,49}$ Ako je potrebno, mogu se upotrebljavati i pomagala za hod kao što su: štap, rolator, ortoze za stabilizaciju, peronealna ortoza, foot up ortoza i bandaža za stopalo. ${ }^{15}$ Potrebno je izbjegavati hod gdje fizioterapeut mora pružati prekomjernu manualnu podršku bolesniku tako da mu oduzme većinu težine tijela, kako ne bi došlo do ozljede terapeuta i/ili bolesnika. Također, ako bolesnik u hodu previše kompenzira (npr. hiperekstenzijom koljena), takav hod treba potpuno obustaviti kako se ne bi povećavala spastičnost i fiksacija. ${ }^{16}$ Osim pravocrtnog hoda, uči se hod ustranu i unatrag. Korak unatrag i ustranu osnova je zaštitnih reakcija. ${ }^{6}$

\subsubsection{Trening gornjih ekstremiteta orijentiran funkcionalnom cilju}

Funkcionalni trening gornjih ekstremiteta odnosi se na facilitaciju dinamičke stabilnosti i selektivne mobilnosti u cilju orijentiranih pokreta gornjih ekstremiteta. Cilj je osposobiti ruku/šaku za optimalnu funkciju u aktivnostima svakodnevnog života, prema potrebama i mogućnostima bolesnika. Aktivnosti uključuju stimulaciju proprioceptivnog i taktilnog osjeta, oslonac na ruku/ šaku, grube i fine hvatove šake i prstiju, koordinaciju pokreta ruke/šake te integraciju motoričkih komponenti u realnu funkcionalnu aktivnost. $2,5,6,8,40,44,50,51$ Trening gornjih ekstremiteta orijentiran funkcionalnom cilju za bolesnika mora biti izazovan, progresivan i optimalno prilagođen te zanimljiv. $U$ stranoj se literaturi opisuje kao pristup top-down, a naziva ga se i: movement science approach, task-specific training, task-related training, functional task practice i goal-directed training. ${ }^{5,6,8,16,39,50,52} \mathrm{U}$ tretmanu je potrebno izabrati funkcionalne ciljeve relevantne za bolesnika i usklađene s njegovim ciljevima.

\subsubsection{Vježbe snaženja muskulature}

Vježbe snage provode se za odgovarajuće mišiće ili mišićne skupine u skladu s funkcionalnim statusom bolesnika. Vježbama snage povećava se mišićna masa, svijest i percepcija tijela, snaga i trofika mišića te se poboljšava funkcija živčano-mišićnog sustava. $5,39,43,44,53,54,55$ Provode se upotrebom različitih vrsta vanjskog opterećenja (utezi, trake, opruge) ili adekvatnim korištenjem mase vlastitog tijela i gravitacije. Opterećenje može biti minimalno do maksimalno, ovisno o funkcionalnom statusu bolesnika, a vježbe se provode u 10 do 12 ponavljanja u tri do pet serija. Vježbe snage potrebno je provoditi prema programu za pojedine mišiće ili mišićne skupine te izbjegavati prevelika opterećenja i nepravilne obrasce vježbanja. ${ }^{43,44,55}$

\subsubsection{Vježbe izdržljivosti}

Vježbe izdržljivosti jesu aktivnosti manjeg intenziteta, ali dužeg trajanja. Uključuju aerobne aktivnosti hodanja, trčanja, vožnje bicikla ili različite oblike vježbi u skladu s funkcionalnim statusom bolesnika. ${ }^{5,56,57}$ Cilj je vježbi izdržljivosti povećanje opće izdržljivosti i kardiovaskularnih sposobnosti te sprječavanje pojave umora. Vježbe izdržljivosti provode se dva do tri puta tjedno u trajanju od 10 do 40 min, intenzitetom 60 do $80 \%$ maksimalnog otkucaja srca. ${ }^{46}$ Trening izdržljivosti potrebno je uključiti u svakodnevne aktivnosti bolesnika te izbjegavati pretjerana opterećenja kardiovaskularnog i lokomotornog sustava. ${ }^{40,43,44,54,55}$

\subsubsection{Respiratorna fizioterapija}

Respiratorna fizioterapija uključuje mobilizaciju prsnog koša i respiratorne muskulature te, po potrebi, postavljanje bolesnika u drenažne položaje i mehaničku aspiraciju trahealnih sekreta. ${ }^{58}$ Kod bolesnika koji aktivno sudjeluju u tretmanu provode se vježbe disanja pri čemu je izdisaj dva do tri puta duži od udisaja. ${ }^{17}$ Respiratorna fizioterapija stimulira koštano-mišićne strukture na optimalnu funkciju disanja, omogućava drenažu dišnih putova, prevenira nastanak zastojne pneumonije te jača respiratornu muskulaturu. Prilikom postavljanja bolesnika u drenažne položaje primjenjuju se i manualne tehnike perkusije i vibracije radi lakšeg izbacivanja sekreta iz pluća. Respiratorni tretman provodi se u trajanju od 20 do $40 \mathrm{~min} .{ }^{59}$ Respiratorna fizioterapija provodi se prema potrebama i funkcionalnom statusu bolesnika.

Stabilnost trupa započinje s dobrom respiratornom kontrolom i obrascem disanja. Osobe koje pokazuju lošiju stabilnost trupa pokazuju i loše obrasce disanja, kao i lošu posturalnu kontrolu. Kod takve osobe poželjno je primjenjivati vježbe koje unaprjeđuju optimalnu posturalnu kontrolu (položaj dijafragme i lumbalne kralježnice) te neuromuskularnu kontrolu dubinskih mišića trupa - dijafragme i dna zdjelice (stabilizacija lumbozdjeličnog kompleksa). Mnogi mišići kojima je funkcija 
posturalna kontrola i stabilizacija istodobno imaju i respiracijsku funkciju, kao npr: dijafragma, $m$. transversus abdominis i mišići dna zdjelice. Važno je održavanje optimalne ravnoteže funkcije ovih mišića. ${ }^{60}$ Optimizacija intraabdominalnog tlaka važan je mehanizam u stabilizacijskom sustavu kralježnice. Disfunkcionalni obrazac disanja dovodi do smanjenja intraabdominalnog tlaka. ${ }^{61} \mathrm{U}$ stabilizaciji trupa proces disanja nije pasivan, nego aktivan. Dijafragma je mišić koji ima svoje antagoniste, dubinske mišiće trupa koje je potrebno aktivirati u treningu. ${ }^{62}$

\subsubsection{Primjena ortoza za korekciju položaja i pomagala za hod}

Primjena ortoza indicirana je individualno prema funkcionalnom statusu i potrebama bolesnika. Ortoze u rehabilitaciji bolesnika s TOM-om jesu: peronealne ortoze (FA), Air Cast, udlage za potporu ili korekciju položaja zglobova i mekih tkiva, suspenzijske mitele i steznici za stabilizaciju zglobova. ${ }^{8,63,64}$ Pomagala za mobilnost bolesnika jesu: invalidska kolica, štap za hodanje, visoki štap, štap s četiri oslonca, niska i visoka okvir hodalica te hodalica rolator. ${ }^{8,65}$ Pravilna primjena ortoza ili pomagala za hod facilitira funkcije, pruža stabilizaciju, potporu ili korekciju mekih tkiva i zglobova te bolji alignment. Poboljšava cirkulaciju te omogućava kompenzacijsku mobilnost bolesniku i prevenira padove. Prekomjerno ili nepravilno korištenje pomagalima za mobilnost može prouzrokovati novu ozljedu ili oštećenje. ${ }^{8,65}$

\subsubsection{Edukacija obitelji i njegovatelja}

Edukacija obitelji i njegovatelja bolesnika uključuje informiranje o mogućnostima postupaka koje osobe iz bolesnikove najbliže okoline mogu provoditi prema preporukama fizioterapeuta.

Edukacija podrazumijeva verbalno pojašnjenje cilja postupka i načina na koji se postupak izvodi, a po potrebi i praktičnu demonstraciju postupka te odgovarajuće pisane materijale. Cilj je provedbe edukacije osigurati integraciju tretmana u cjelodnevno funkcioniranje bolesnika, omogućiti bolje funkcioniranje bolesnika u svakodnevnim aktivnostima te aktivno uključiti obitelj u proces rehabilitacije, a samim se time potiče bolja socijalizacija bolesnika u obitelji. Članove obitelji ili njegovatelje trebalo bi upoznati i poticati da pomažu kod pozicioniranja bolesnika i pasivnih vježbi pokretanja. Kako bolesnik napreduje, obitelj može pomoći u pokretljivosti bolesnika u krevetu, transferima, kretanju u invalidskim kolicima i njezi. Važno je educirati članove obitelji o pravilnoj mehanici tijela kod pomicanja bolesnika kako bi se izbjegle ozljede. ${ }^{41,66,67}$ Edukacija se provodi u skladu s funkcionalnim sposobnostima i potrebama bolesnika te prema sposobnosti članova obitelji i njegovatelja da postupak svladaju na učinkovit i siguran način. Obitelji je potrebno omogućiti razumijevanje određenih reakcija bolesnika. Važno je obitelj educirati o strategijama koje je moguće primijeniti kako bi se izbjegli ili kontrolirali neželjeni obrasci ponašanja. ${ }^{41,66,67}$ Član obitelji ili skrbnik dužan je pri dolasku na odjel potpisati informirani pristanak za boravak osobe u pratnji uz bolesnika na rehabilitaciji nakon oštećenja mozga ili leđne moždine. ${ }^{68,69}$

\section{Zaključak}

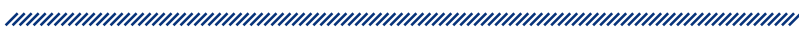

Fizioterapijski protokol za tretman odraslih bolesnika nakon TOM-a sadrži potrebne standarde fizioterapeutske procjene i tretmana pacijenata. Protokol je vodič fizioterapeutu u kliničkom zaključivanju te preporučuje osnovne metode procjene koje bi se trebale primjenjivati u fizioterapijskom procesu. Na temelju procjene funkcionalnog statusa bolesnika, protokol vodi fizioterapeuta u odabir i primjenu odgovarajućih metoda tretmana koje će omogućiti najbolje učinke, odnosno optimalan oporavak bolesnika. U protokolu su sadržane metode procjene i tretmana koje su stručno i znanstveno utemeljene, usklađene su s edukacijskom razinom i organizacijskim mogućnostima fizioterapije u Hrvatskoj te kao takve mogu biti primjenjivane u kliničkoj praksi. Klinička primjena protokola fizioterapijskog tretmana odraslih bolesnika s povredama mozga može znatno pridonijeti poboljšanju kvalitete i ujednačavanju dijagnostičko-terapijskih fizioterapijskih postupaka na razini različitih ustanova koje se bave rehabilitacijom bolesnika s kraniocerebralnim oštećenjima. Protokol za tretman odraslih bolesnika nakon TOM-a prvi je dokument ove vrste u hrvatskoj fizioterapiji te će ga u budućnosti biti potrebno stalno nadograđivati i prilagođavati novim stručnim, znanstvenim i organizacijskim potrebama fizioterapije. 


\section{Referencije:}

1. Sajko T, Rotim K. Neurokirurgija. Zagreb: Zdravstveno veleučilište; 2010.

2. Mills V, Cassidy JW, Katz DI. Neurologic rehabilitation: a guide to diagnosis, prognosis, and treatment planning. Oxford: Blackwell Science; 1997.

3. Ivančević Ž. MSD priručnik dijagnostike i terapije. 18. američko izdanje, 2. hrvatsko izdanje. U: Kardiologija. Split: PLACEBO doo. 2010: 708-745.

4. Bakran Ž, Schnurrer-Luke-Vrbanić T, Kadojić M, Moslavac S, Vlak T, Grazio S. Smjernice u rehabilitaciji bolesnika s traumatskom ozljedom mozga. Fizikalna i rehabilitacijska medicina. 2015; 27(3-4): 270-301.

5. Scottish Intercollegiate Guidelines Network (SIGN). Dostupno na: http://www.sign.ac.uk

6. Grozdek Čovčić G, Maček Z. Neurofacilitacijska fizioterapija. Zagreb: Zdravstveno veleučilište; 2011.

7. World Confederation for Physical Therapy (WCPT). Dostupno na: www.wcpt.org/policy/ps-descriptionPT.

8. Edwards S., ur. Neurological Physiotherapy: A problemsolving approach. 2. izd. Edinburgh: Elsevier Health Sciences; 2002.

9. Medical dictionary. Dostupno na: https://medical-dictionary.thefreedictionary.com/protocol

10. Hrvatska komora fizioterapeuta. Zakon o fizioterapeutskoj djelatnosti, članak 17. Dostupno na: https://www.zakon.hr/z/398/Zakon-o-fizioterapeutskoj-djelatnosti

11. World Health Organization. International Classification of Functioning, Disability and Health. Dostupno na: http://www.who.int/classifications/icf/en/

12. Edwards I, Braunack-Mayer A, Jones M. Ethical reasoning as a clinical-reasoning strategy in physiotherapy. Physiotherapy. 2005; Vol: 91(4): 229-236.

13. Atkinson HL, Nixon-Cave K. A tool for clinical reasoning and reflection using the International Classification of Functioning, Disability and Health (ICF) framework and patient management model. Physical therapy. 2011; 91(3): 416-430.

14. Edwards I, Jones M, Carr J, Braunack-Mayer A, Jensen GM. Clinical reasoning strategies in physical therapy. Physical therapy. 2004; 1;84(4): 312-330.

15. Davies MP. Starting Again. Berlin, Heidelberg, New York, London, Pariz, Tokio, Hong Kong, Barcelona, Budimpešta: Springer-Verlag; 1994.

16. Davies MP. Steps To Follow. Berlin, Heidelberg, New York, Tokio: Springer-Verlag; 1985.

17. Gosselink R, Clerckx B, Robbeets C, Vanhullebusch T, Vanpee G, Segers J. Physiotherapy in the Intensive Care Unit. Neth J Crit Care. 2011; 15: 66-75.

18. Hrvatska komora fizioterapeuta. Protokoli postupanja i evaluacija u fizioterapiji. Dostupno na: http://www.hkf. hr/Naslovna/tabid/38/Default.aspx
19. Hrvatska komora fizioterapeuta. Odluka Vijeća Komore za pečat prvostupnika fizioterapeuta. Dostupno na: http://www.hkf.hr/LinkClick.aspx?fileticket=OcLZf\%2f4I iPw\%3d\&tabid $=62 \&$ mid $=395$

20. Rappaport M i sur. Disability rating scale for severe head trauma patients: coma to community. Archives of Physical Medicine and Rehabilitation, 1982; 63: 118-123.

21. Bohannon RW, Smith MB. Interrater Reliability of a Modified Ashworth Scale of Muscle Spasticity. Physical Therapy. 1987; 67(2): 206-207.

22. Person CU, Danielsson A, Sunnerhagen KS, GrimbyEkman A, Hansson PO. Timed up \& Go as a measure for longitudinal change in mobility after stroke - Postural Stroke Study in Gotenberg (POSTGOT). Journal of neuroengineering and rehabilitation. 2014; 11: 83.

23. Jones C, Rikli R i sur. A 30-s chair-stand test as a measure of lower body strength in community-residing older adults. Research Quarterly for Exercise and Sport. 1999; 70(2): 113.

24. Kersten P, Küçükdeveci AA, Tennant A. The use of the visual analogue scale (VAS) in rehabilitation outcomes. J Rehabil Med. 2012; 44: 609-610.

25. Huskisson EC. Measurement of pain. Lancet. 1994; 2: 1127-1131.

26. Jansen MP, Karoly P, Brauer S. The measurement of clinical pain intensity: a comparision of six methods. Pain. 1986; 27: 117-126.

27. Jansen MP, Chen C, Brugger AM. Interpretation of visual analog scale ratings and change scores: a reanalysis of two clinical trials of postoperative pain: The Journal of Pain. 2003; 4: 407-414.

28. Kaltenborn FM. Manual Mobilization of the Joints. 8. izd. Oslo: Norli; 2014.

29. Pickenbrock H, Ludwig VU, Zapf A, Dressler D. Conventional versus neutral positioning in central neurological disease: a multicenter randomized controlled trial. Deutsches Ärzteblatt International. 2015; 16; 112(3): 35-42.

30. Maček Z, Mandić M. Pozicioniranje nepokretnog neurološkog pacijenta. Acta medica Croatica. 2016; 70(1): 59-63.

31. Kader E, Bitensky NK, Sitcoff E. Positioning. StrokEngine. 2015; 1-6. Dostupno na: http://www.strokengine.ca/patient-info/positioning-info/

32. Hermans MH, Call E. Failure to Reposition After Sliding Down in Bed Increases Pressure at the Sacrum and Heels. Wounds. 2015; 27(7): 191-198.

33. Liepert J. How Evidence Based Is the Positioning of Patients With Neurological Illness?. Deutsches Ärzteblatt International. 2015; 112(3): 33-34.

34. Drummond SS, McDonough M. Multimodal Sensory Stimulation Treatment for an Individual with Chronic \& Severe TBI. Southeast Missouri State University ASHA

35. Brethour MK, Nyström KV, Broughton S, Kiernan TE, Perez A, Handler D, et al. Controversies in acute stroke treatment. Advanced Critical Care. 2012 ;23: 158-172.

36. Bernardth J, English C, Lohnson L i sur. Early Mobilisation After Stroke. Stroke 2015; 46: 1141-1146. 
37. Cumming TB, Thrift AG, Collier JM, Churilov L, Dewey HM, Donnan G i sur. Very early mobilization after stroke fast-tracks return to walking: further results from the phase II AVERT randomized controlled trial. Stroke. 2011; 42: 153-158.

38. Elfyn PC, Thomas O, Summers F, Whyte M, Hutchinson PJ, ur. Head injury. Cambridge, New York, Melbourne, Madrid, Cape Town, Singapore, São Paulo: Cambridge University Press; 2009.

39. Gjelsvik BEB. The Bobath concept in adult neurology. Stuttgart, New York: Thieme; 2008.

40. Raine S, Meadows L i Lynch-Ellerington M. Bobath Concept. Oxford: Wiely-Blackwel; 2009.

41. Martin ST, Kessler M. Neurologic interventions for physical therapy. 2. izd. Missouri: Saunders Elsevier; 2006.

42. Models systems knowledge translation center, Dostupno na: http://www.msktc.org/tbi/factsheets/Balance-Problems-After-Traumatic-Brain-Injury

43. Ewing GC, Blissmer B, Deschenes MR, Franklin BA, LaMonte MJ, Lee IM i sur. Quantity and quality of exercise for developing and maintaining cardiorespiratory, musculoskeletal, and neuromotor fitness in apparently healthy adults: guidance for prescribing exercise. Medicine \& Science in Sports \& Exercise. 2011; 43(7): 1334-1359.

44. Billinger SA, Arena R, Bernhardt J, Eng JJ, Franklin BA, Johnson CM, et al. Physical Activity and Exercise Recommendations for Stroke Survivors. Stroke. 2014;45: 2532-2553.

45. De Haart M, Geurts AC, Huidekoper SC, Fasotti L, Van Limbeek J. Recovery of standing balance in postacute stroke patients: A rehabilitation cohort study. Arch Phys Med Rehabil. 2004; 85(6): 886-895.

46. Whittle MW. Gait Analysis an introduction. 4. izd. B.H. Elsevier; 2007.

47. Hausdorff JM, Alexander NB. Gait Disorders Evaluation and Management. Boca Raton, London, New York, Singapur: Taylor \& Francis Group; 2005.

48. Grozdek Čovčić G. Učinci neurofacilitacijskog tretmana i specifičnih mobilizacija na funkciju hoda kod osoba s hemiparezom nakon moždanog udara. Disertacija. Zagreb: Kineziološki fakultet; 2016.

49. Eng JJ, Tang PF. Gait training strategies to optimize walking ability in people with stroke: A synthesis of the evidence. Expert Review of Neurotherapeutics. 2007; 7(10): 1417-1436.

50. Harvey RL, Macko RF, Stein J, Winstein CJ, Zorowitz RD. Stroke Recovery and Rehabilitation, Demos Medical Publishing; 2008.

51. Arya KM., Verma R, Garg RK, Agarwal M, Aggarwal G. Meaningfull task-specific training (MTST) for stroke rehabilitation: a randomized controlled trial. Top Stroke Rehabil. 2012; 19(3): 193-211.

52. Dean C. Group task-specific circuit training for patients discharged home after stroke may be as effective as individualised physiotherapy in improving mobility. Journal of Physiotherapy. 2012; 58: 69.

53. Patten C, Lexell J, Brown HE. Weakness and strength training in persons with poststroke hemiplegia: Rationale, method, and efficacy. Journal of Rehabilitation Reasearch \& Development. 2004; 4: 293-312.

54. Saunders DH, Sanderson M, Hayes S, Kilrane M, Greig CA, Brazzelli M, et al. Physical fitness training for stroke patients. Cochrane Database of Systematic Reviews. 2016; 1-3. Dostupno na: http://onlinelibrary.wiley.com/ doi/10.1002/14651858.CD003316.pub6/pdf, (pristupljeno 12.4.2018.).

55. Brogĺrdh C, Lexell J. Effects of cardiorespiratory fitness and muscle resistance training after stroke. Physical Medicine \&Rehabilitation. 2012; 4: 901-907.

56. Dalgas U, Ingemann-Hansen T, Stenager E, Physical Exercise and MS -Recommendations. The International MSJournal. 2009; 16: 5-11.

57. Chin LMK, Chan L, Woolstenhulme JG, Christensen EJ, Shenouda CN, Keyser RE. Improved Cardiorespiratory Fitness with Aerobic Exercise Training in Individuals with Traumatic brain injury. J Head Trauma Rehabil. 2015; 30(6):382-390.

58. Hellweg S. Effectiveness of Physiotherapy and Occupational Therapy after Traumatic Brain Injury in the Intensive Care Unit. Critical Care Research and Practice. 2012;1-5.

59. Cystic Fibrosis foundation. Dostupno na: https://www. cff.org/PDF-Archive/Introduction-to-Postural-Drainageand-Pecussion/

60. Boyle KL, Olinick J, Lewis C. The value of blowing up a balloon. North American Journal of Sports Physical Therapy. 2010; 5(3): 179-188.

61. Marković G. Funkcionalni trening ravnoteže i stabilizacije zglobova (seminar). Zagreb: Motus Melior akademija funkcionalnog pokreta; 2016.

62. DeFranco J, Smith J. Hard-core. New York: Diesel Strength; 2012.

63. Ring H, Treger I, Gruendlinger L, Hausdorff JM. Neuroprosthesis for footdrop compared with an ankle-foot orthosis: effects on postural control during walking. J Stroke Cerebrovasc Dis. 2009; 18: 41-47.

64. Xu GQ, Lan Y, Huang DF, Chen ZH, Ding MH. Effects of ankle-foot orthosis on gait stability and balance control in patients with hemiparetic stroke, Zhonghua Yi Xue Za Zhi. 2011; 5; 91(13): 890-893.

65. Medical News Today. Dostupno na: https://www.medicalnewstoday.com/articles/318463.php

66. Hebert D, Lindsay MP, McIntyre A, Kirton A, Rumney PG, Bagg S i sur. Canadian stroke best practice recommendations: Stroke rehabilitation practice guidelines. International Journal of Stroke. 2016; 11(4): 459-484.

67. Miller KK, Porter RE, DeBaun-Sprague E, Van Puymbroeck M, Schmid AA. Exercise after Stroke: Patient Adherence and Beliefs after Discharge from Rehabilitation. Topics in Stroke Rehabilitation. 2016; 4-6.

68. Lalit K i sur. Training carers of stroke patients: randomised controlled trial. BMJ. 2004; 328:1099.

69. Miller KK, Porter RE, DeBaun-Sprague E, Van Puymbroeck M, Schmid AA. Exercise after Stroke: Patient Adherence and Beliefs after Discharge from Rehabilitation, Topics in Stroke Rehabilitation. 2017; 24(2): 142-148. 


\section{PHYSIOTHERAPEUTIC PROTOCOL IN ADULT PATIENTS AFTER TRAUMATIC BRAIN INJURY}

\begin{abstract}
Introduction: The protocols include the guidelines and recommendations of physiotherapists, doctors and other team members in the rehabilitation of patients after traumatic brain injury. Traumatic brain injury (TBI) is a consequence of physical force that causes primary or secondary brain damage. After brain injury, the functional status of patients may vary from active participation in rehabilitation processes to persistent vegetative state. The purpose of the protocol development is to ensure the standard quality and uniformity of physiotherapy in the process of neurorehabilitation of adult patients with TBI. The protocol defines the methods of assessment, setting goals, and methods of physiotherapy intervention.
\end{abstract}

Methods: The physiotherapy protocol is based on a review of relevant neurophysiotherapy literature, which includes clinical guidelines, scientific and expert articles, and secondary sources of information.

Results and discussion: Physiotherapy assessment is based on examinations, tests and measurements. The recommended standard assessment includes a Disability Rating Scale, a modified Ashworth scale, a Timed Up and Go Test, a Sit to Stand Test, a Berg Balance Scale, a visual analogue pain scale and goniometry. Planning and implementation of physiotherapy interventions in patients in a coma, vegetative and minimally conscious state include: prevention of complications of inactivity, multisensory stimulation of consciousness, transfer facilitation, positioning in a wheelchair, facilitation of head and body control and voluntary movement of the extremities. Planning and implementation of physiotherapy interventions in patients who actively participate in therapeutic processes include: specific muscle mobilization, stimulation of active positioning while lying down, sitting up, standing up, walking reeducation, functional upper extremity training, balance and coordination exercises, strength and endurance exercises, use of orthoses, and education of patients and their families. Conclusion: The physiotherapeutic protocol can ensure the uniformity and quality of performing physiotherapeutic procedures in rehabilitation of adult patients with TBI, where the recommended assessment and treatment methods are professional and scientific evidence based.

Keywords: neurophysiotherapy, TBI, protocol, assessment, intervention 